\title{
ANALISIS PENGENDALIAN RISIKO TERHADAP PENINGKATAN KINERJA PEKERJAAN KONSTRUKSI (STUDI KASUS ASRAMA HAJI GORONTALO)
}

\author{
Evan Kusuma Wijaya*1, Edhi Wahjuni Setyowati ${ }^{2}$ dan Yulvi Zaika ${ }^{2}$ \\ ${ }^{1}$ Mahasiswa / Magister / Teknik Sipil / Universitas Brawijaya \\ ${ }^{2}$ Dosen / Teknik Sipil / Universitas Brawijaya \\ Korespondensi : evan.k.wijaya@gmail.com
}

\begin{abstract}
A good construction management can support the acceleration of the infrastructure construction and a low performance in implementation of the construction projects will lead to delay and cost overrun. This paper is intended to identify the risk factors which affect to performance of construction project. Gorontalo Hajj Dormitory construction project are not completed within the estimated scheduled and cost. Data in this research were collected through questionnaires from stakeholders. Regression model of an analysis result then simulated with Monte Carlo method and the variables in this model are the most dominant risk factor which influence on a performance. The most dominant risk for cost and schedule performance is bad condition during construction, incorrect of implementation methods, rework and equipment failure. The cost and schedule performance of the construction work are in poor condition. Generated statistical model is aligned with Earn Value Method and can be apply on the field.
\end{abstract}

Keywords: Earned Value Analysis, Monte Carlo simulation, Risk analysis.

\section{PENDAHULUAN}

Manajemen konstruksi yang baik dapat mendukung program percepatan pembangunan infrastruktur pemerintah, kontraktor sebagai pelaksana juga K/L/D/I di pusat maupun di daerah sebagai pemilik harus meningkatkan pengawasan serta pengendalian terhadap pembangunan tersebut, kemampuan mengidentifikasi, mengelola serta mengendalikan risiko yang dapat terjadi dalam pelaksanaan suatu proyek harus dipahami secara benar dan diaplikasikan oleh kontraktor maupun pejabat berwenang pada lembaga pemerintah agar pelaksanaan pembangunan tetap pada jadwal dan anggaran yang telah ditetapkan.

Definisi sukses tidaknya suatu proyek dapat diukur apabila pada seluruh pelaksanaan aktivitas proyek dapat terlaksana baik meskipun dengan segala keterbatasan (constraint) yang ada, yaitu keterbatasan waktu, biaya dan mutu. Dalam dua dasawarsa terakhir, ukuran keberhasilan suatu proyek telah berkembang menjadi tuntutan pemenuhan periode waktu yang dialokasikan/telah ditentukan, dalam rentang biaya yang dianggarkan, hasil atau spesifikasi yang tepat/baik, dapat diterima oleh pelanggan/pemilik (Kerzner, 2003)[1].

Risiko merupakan hal yang bisa saja terjadi baik secara alami ataupun dari berbagai kemungkinan, kemampuan dalam mempersiapkan manajemen terhadap risiko yang dapat terjadi dalam pelaksanaan konstruksi haruslah dimiliki, sehingga dampak risiko yang telah diidentifikasi sebelumnya dapat diminimalkan dan dikendalikan. Risiko yang tidak tertanggulangi dapat mengakibatkan kerugian serta kinerja proyek yang buruk.

Dari beberapa penelitian yang pernah dilakukan sebelumnya, terdapat beberapa variabel risiko yang mungkin terjadi pada proyek. Dari beberapa variabel risiko yang dapat terjadi dalam suatu proyek, ada satu risiko yang paling dominan terjadi dan memberikan dampak yang signifikan. Pada tesis yang ditulis Yahya (2011) [2], faktor risiko yang paling signifikan menurunkan kinerja biaya adalah sering terjadinya redesain (rework). Demikian pula pada jurnal Utama dan Setiadi (2013)[3], faktor cuaca yang buruk adalah faktor risiko yang paling dominan terjadi. Sasaran penelitian sebagai berikut: 
1. Mendapatkan variabel-variabel risiko dominan yang berpengaruh terhadap kinerja biaya dan waktu.

2. Untuk Mengembangkan pemodelan dan pengelolaan risiko pada variabel-variabel risiko tersebut terhadap kinerja biaya dan waktu.

3. Untuk menghitung nilai kinerja dengan metode Nilai Hasil (Earn Value method) dan membandingkan dengan hasil pemodelan statistik.

4. Untuk mengetahui dampak dan penyebab risiko yang berpengaruh terhadap kinerja biaya dan waktu proyek.

\section{TINJAUAN PUSTAKA}

\subsection{Manajemen Risiko Proyek}

Manajemen risiko proyek adalah proses sistematis untuk merencanakan, mengidentifikasi, menganalisis, merespons dan mengendalikan risiko proyek. Tujuannya untuk meningkatkan peluang dan dampak peristiwa positif, dan mengurangi peluang dan dampak peristiwa yang merugikan proyek (PMBOK, 2013)[4].

Dalam manajemen risiko proyek terdapat beberapa tahapan yang dilakukan, yaitu :

1. Perencanaan manajemen risiko adalah proses mendefinisikan bagaimana cara melakukan manajemen risiko untuk suatu proyek.

2. Identifikasi risiko adalah suatu proses untuk menentukan apa saja risiko yang bisa terjadi dan dapat memberikan dampak terhadap proyek dan mendokumentasikan karakteristiknya masing-masing.

3. Analisis risiko kualitatif adalah proses untuk memprioritaskan risiko lebih lanjut atau melakukan penilaian risiko yang telah diidentifikasi dengan menggabungkan kemungkinan terjadi serta dampak yang ditimbulkan.

4. Analisis risiko kuantitatif adalah proses analisis numerik dari dampak risiko yang telah diidentifikasi pada tujuan proyek secara keseluruhan.

5. Perencanaan penanggulangan risiko adalah tindakan yang merupakan proses, teknik, dan strategi untuk menanggulangi risiko yang mungkin timbul.

6. Kontrol risiko adalah proses untuk mengimplementasikan keluaran dari perencanaan penanggulangan risiko, melacak risiko yang teridentifikasi, monitoring sisa risiko, mengidentifikasi risiko baru, dan mengevaluasi keefektifan penanganan terhadap risiko sepanjang pelaksanaan proyek.
Dari tahapan tersebut dapat melakukan analisis dampak, penyebab dan respons terhadap risiko.

\subsection{Kinerja Proyek}

Kinerja memiliki pengertian yang beraneka ragam berkaitan dengan aspek ekonomi, kesejahteraan, teknologi, dan sumber daya. Pembahasan mengenai kinerja lebih banyak difokuskan pada aspek keluaran sejumlah tertentu (Situmorang, 2009)[5]. Ukuran atas kinerja dapat dilihat berdasarkan aspek biaya, waktu, dan kualitas (Alinaitwe, 2008) [6].

Metode "Nilai Hasil" (Earned Value) adalah suatu metode pengendalian yang digunakan untuk mengendalikan biaya dan jadwal proyek secara terpadu. Metode ini memberikan informasi status kinerja proyek pada suatu periode pelaporan dan memberikan informasi prediksi biaya yang dibutuhkan dan waktu untuk penyelesaian seluruh pekerjaan berdasarkan indikator kinerja saat pelaporan (PMBOK, 2013)[4].

Untuk menghitung kinerja biaya dan waktu, indikator yang perlu diketahui yaitu:

1. Kemajuan pekerjaan aktual berdasarkan anggaran biaya / Budget Cost of Work Performance (BCWP) adalah gambaran dari kemajuan pekerjaan pada suatu titik waktu tertentu.

2. Biaya aktual / Actual Cost of Work Performance (ACWP) adalah keseluruhan sumber daya yang telah dihabiskan untuk mencapai rencana pekerjaan sesuai yang telah dijadwalkan (atau pada periode waktu tertentu).

3. Kemajuan pekerjaan seharusnya / Budget Cost of Work Scheduled (BCWS) adalah seberapa jauh pekerjaan proyek seharusnya pada suatu titik tertentu dalam jadwal proyek.

4. Indeks kinerja biaya / Cost Performance Index $(C P I)$ bernilai kurang dari satu menunjukkan kinerja biaya yang buruk. CPI bernilai lebih dari satu menunjukkan kinerja biaya yang baik. Persamaan untuk menghitung nilai CPI adalah :

$C P I=B C W P / A C W P$

5. Indeks kinerja waktu / Schedule Performance Index (SPI) bernilai kurang dari satu menunjukkan kinerja waktu yang buruk.

SPI bernilai lebih dari satu menunjukkan kinerja waktu yang baik. Persamaan untuk menghitung nilai CPI adalah :

$S P I=B C W S / A C W P$ 


\subsection{Analisis Statistik}

Pengolahan data dianalisis secara statistik dengan menggunakan bantuan program Statistical Program for Social Science (SPSS) yang merupakan program pengolah data statistik. Tahapan-tahapannya adalah :

1. Uji validitas dan reliabilitas digunakan untuk mengetahui konsistensi atau stabilnya suatu jawaban. Instrumen yang valid berarti alat ukur yang digunakan untuk mendapatkan data itu adalah valid berarti instrumen tersebut dapat digunakan untuk mengukur apa yang seharusnya diukur, dan dikatakan reliabel jika memberikan hasil yang tetap apabila diteskan berkali-kali. Koefisien korelasi dilakukan dengan persamaan yang ditemukan oleh Karl Pearson (Widiyanto, 2010)[7]:

$\rho=\frac{n \sum X Y_{i}-\sum x \sum x_{i}}{\sqrt{\sum X^{2}-\left(\sum X^{3}\right)} \cdot \sqrt{n \sum x_{i}-\left(\sum x_{i}^{3}\right)}}$

dengan :

$\rho \quad=$ koefisien korelasi

$\mathrm{X}=$ skor item $\mathrm{X}$

$\mathrm{X}_{\mathrm{i}} \quad=$ skor total item $\mathrm{X}$

$\mathrm{n} \quad=$ banyaknya responden

2. Uji reliabilitas digunakan untuk mengetahui konsistensi alat ukur, apakah alat ukur itu tetap dapat diandalkan dan konsisten jika digunakan lagi. Uji dilakukan dengan melihat nilai alfa Cronbach. Persamaan yang ditemukan oleh Lee Cronbach digunakan untuk mencari nilai ini adalah :

$$
\alpha=\left[\frac{k}{k-1}\right]\left[1-\frac{\sum a_{b^{2}}}{a_{1^{2}}}\right]
$$

dengan :

$\alpha \quad=$ reliabilitas instrumen (alfa Cronbach)

$\mathrm{K}$ = banyaknya item pertanyaan

$\sum a_{b^{2}}=$ jumlah varian butir

$a_{1^{2}}=$ varian total

3. Analisis korelasi digunakan untuk mempelajari hubungan antara dua variabel, yaitu variabel pengharapan (predictor) yang merupakan variabel terikat dengan variabel-variabel kriteria ukuran yang merupakan variabel bebas. Analisis korelasi menggunakan persamaan $\mathrm{Bi}$ variate Pearson seperti pada uji validitas dengan persamaan :

$\rho=\frac{n \sum X Y-\sum X \sum Y}{\sqrt{\sum X^{2}-\left(\sum X^{2}\right) \sqrt{n \sum Y-\left(\sum Y^{2}\right)}}}$

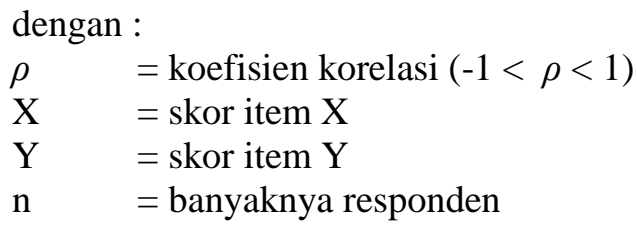

4. Analisis regresi bertujuan untuk mengetahui pengaruh suatu variabel terhadap variabel lain. Analisis regresi yang digunakan adalah analisis linear berganda dengan metode stepwise pada SPSS untuk mendapatkan model matematis dari hubungan variabel $\mathrm{X}$ dengan variabel $\mathrm{Y}$. Regresi stepwise merupakan salah satu metode untuk mendapatkan model terbaik dari analisis regresi. Variabel yang pertama kali dimasukkan adalah variabel yang korelasinya tertinggi dan signifikan dengan variabel terikat, variabel yang masuk kedua adalah variabel dalam percobaan kedua yang paling tinggi korelasi dan signifikan, proses ini dilakukan sampai tidak mendapatkan lagi variabel yang berkorelasi dan signifikan (Draper \& Smith, 2014) [8]. Persamaan analisis regresi secara umum adalah :

$$
Y=K+\beta_{1} X_{1}+\beta_{2} X_{2}+\ldots \ldots+\beta_{i} X_{i}
$$

$$
\begin{aligned}
& \text { dengan : } \\
& \mathrm{Y} \quad=\text { Kinerja (variabel terikat) } \\
& \mathrm{K} \quad=\text { Konstanta } \\
& \beta \mathrm{i} \quad \text { Konstanta prediktor (variabel X ke..i) } \\
& \mathrm{Xi} \quad=\text { Prediktor ke..i }
\end{aligned}
$$

5. Pengujian model regresi dilakukan dengan menggunakan beberapa pengujian yaitu :

- Uji multikolinearitas digunakan untuk mengetahui ada atau tidaknya hubungan linear antara tiap-tiap variabel bebas dalam model regresi. Persyaratan untuk dapat dikatakan terbebas dari multikolinearitas adalah nilai toleransi lebih besar dari 0,10 dan nilai varian faktor inflasi (VIF) tidak boleh lebih dari 10 (Santoso, 2012) [9]. Koefisien korelasi haruslah lemah, jika terjadi korelasi kuat maka dapat terjadi masalah multikolinearitas (Ghozali, 2006) [10]. Persamaan untuk mencari toleransi dan VIF adalah :

$$
\begin{array}{ll}
\text { Toleransi } & =1-R^{2} \\
\text { VIF } & =1 / \text { toleransi }
\end{array}
$$

dengan :

$R^{2} \quad=$ Nilai koefisien determinasi

- Uji koefisien determinasi (uji $R^{2}$ ) digunakan untuk mengukur besarnya kontribusi variabel bebas terhadap variasi variabel terikat (Santoso, 
2012)[9]. Untuk mencari nilai koefisien determinasi $R^{2}$ digunakan persamaan :

$R^{2}=\frac{\left(\beta_{1} \times \sum x_{1} Y\right)+\left(\beta_{2} \times \sum X_{2} Y\right)+\cdots+\left(\beta_{i} \times \sum x_{i} Y\right)}{\sum Y^{2}}$

dengan :

$\beta \mathrm{i}=$ Konstanta dari prediktor (variabel $\mathrm{X}$ ke..i)

$X_{1}=$ Nilai butir $X_{1}$

- Uji F digunakan untuk menguji variabel-variabel bebas secara bersama-sama terhadap variabel terikat (Sugiyono, 2013)[11]. Untuk menghitung nilai $\mathrm{F}$ digunakan persamaan :

$F_{\text {hitung }}=\frac{R^{2} /(k-1)}{\left(1-R^{2}\right) /(n-k)}$

dengan :

$\mathrm{k}=$ Jumlah variabel bebas pembentuk model

$\mathrm{n}=$ jumlah sampel

- Uji t menunjukkan seberapa jauh pengaruh satu variabel bebas secara individual dalam menerangkan variabel terikat. (Ghozali, 2006) [10]. Persamaan untuk uji t adalah :

$t_{\text {hitung }}=\frac{r^{2} \sqrt{n-2}}{\sqrt{1-r^{2}}}$

dengan :

$\mathrm{r} \quad=$ Korelasi parsial

$\mathrm{n} \quad=$ jumlah sampel

hasil $\mathrm{t}$ hitung kemudian dikonsultasikan dengan $\mathrm{t}$ tabel.

- uji auto korelasi (Durbin-Watson Test) untuk menguji ada atau tidaknya auto korelasi antara variabel-variabel yang diteliti. (Rawlings, 1998) [12]. Pengujian dilakukan dengan menggunakan persamaan :

$d=\frac{\sum_{i=2}^{n}\left(e_{i}-e_{i-1}\right)^{2}}{\sum_{i=1}^{n} \theta_{i}^{2}}$

dengan :

$\mathrm{d}=$ Durbin Watson

$\mathrm{e} \quad=$ nilai residual

\subsection{Simulasi Monte Carlo}

Simulasi Monte Carlo adalah metode untuk menganalisis perambatan ketidakpastian, di mana tujuannya adalah untuk menentukan bagaimana variasi acak mempengaruhi sensitivitas, performa atau reliabilitas dari sistem yang sedang dibentuk. Simulasi Monte Carlo digolongkan sebagai metode sampling karena input dibangkitkan secara acak dari suatu distribusi probabilitas untuk proses sampling dari suatu populasi nyata. Oleh karena itu, suatu model harus memilih suatu distribusi input yang paling mendekati data yang dimiliki (Rubinstein, 2007) [13].

\section{METODE PENELITIAN}

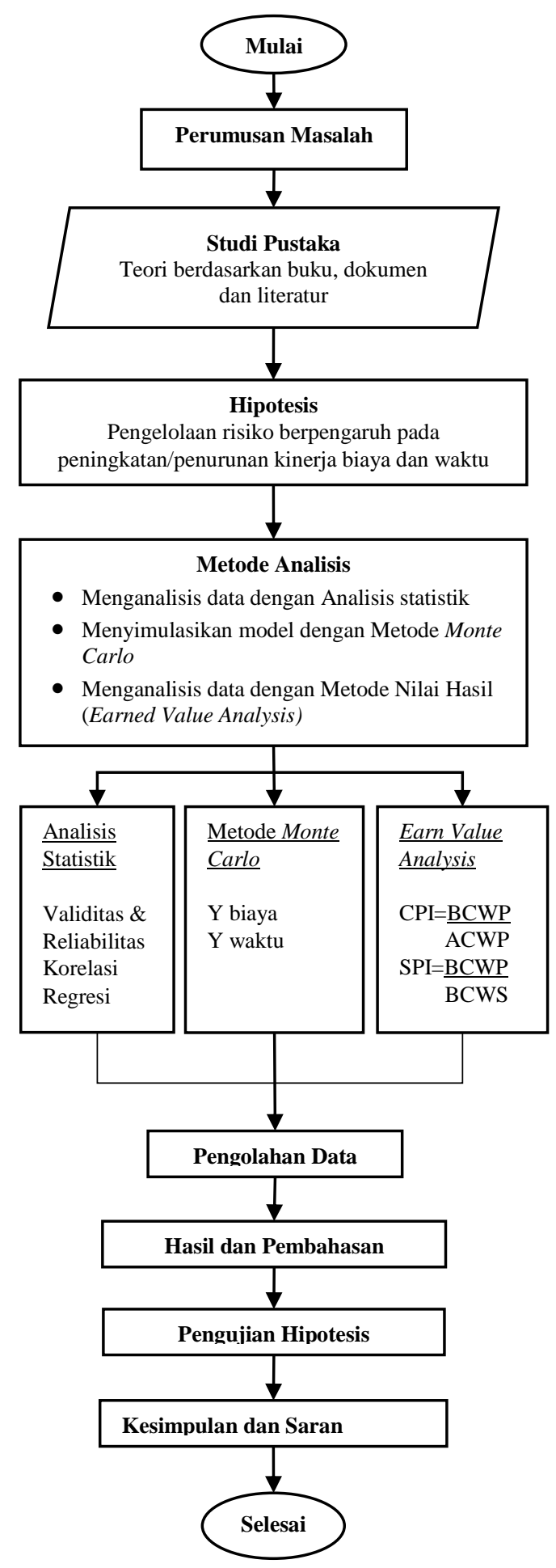

Gambar 1. Diagram alir penelitian 


\subsection{Variabel Penelitian}

Variabel pada penelitian ini diperoleh dari penelitian terdahulu oleh N.S. Asmarantaka (2014) [14], Nurlela, H. Suprapto (2014) [15], Yahya (2011) [2], Andi (2005) [16], Utama dan Setiadi (2013) [3], Janaka YR (2006) [17] dan wawancara. Variabel bebas pada penelitian ini yaitu:

1. Faktor bahan dan peralatan :

- Kekurangan bahan konstruksi (X1)

- Kelangkaan produksi material (X2)

- Kesalahan pengiriman material dan perala$\tan$ (X3)

- Keterlambatan pengiriman material dan peralatan (X4)

- Kesulitan mendapatkan material sesuai spesifikasi (X5)

- Perubahan spesifikasi (X6)

- Kualitas bahan dan peralatan yang kurang bagus (X7)

- Kerusakan peralatan (X8)

- Kurangnya peralatan (X9)

- Kondisi alat tidak optimal (X10)

2. Faktor Tenaga Kerja :

- Produktivitas tenaga kerja yang rendah (X11)

- Kurangnya tenaga kerja (X12)

- Tenaga inti proyek yang kurang kompeten (X13)

- Kurangnya kerja sama tim (X14)

- Banyaknya kerja lembur (X15)

3. Faktor Pelaksanaan Konstruksi :

- Kesalahan desain (X16)

- Perubahan desain (X17)

- Detail tidak jelas (X18)

- Kurangnya pengetahuan konstruksi (X19)

- Kurangnya pengetahuan tentang karakter bahan (X20)

- Pemborosan pemakaian material di lapangan (X21)

- Metode pelaksanaan yang salah (X22)

- Terjadinya redesain (rework) (X23)

- Penambahan lingkup kerja (X24)

4. Faktor Lingkungan dan K3 :

- Cuaca buruk saat aktivitas konstruksi (X25)

- Kurangnya antisipasi terhadap keadaan alam (X26)

- Gangguan sosial dari masyarakat sekitarnya (X27)

- Tingkat keamanan lingkungan proyek (X28)

- Perselisihan dan pemogokan kerja (X29)
- Bencana alam (force majeure) (X30)

- Kecelakaan kerja (X31)

\subsection{Populasi dan Sampel}

Populasi pada penelitian ini adalah perencana, kontraktor, konsultan manajemen konstruksi serta beberapa pemangku kepentingan (stakeholder) yang melaksanakan proyek pembangunan Asrama Haji Gorontalo. Jumlah sampel dalam penelitian ini berdasarkan jumlah sampel minimal untuk metode korelasional berdasarkan Gay dan Diehl (1992) yaitu 30 data. Responden adalah tim inti dari setiap perusahaan tersebut dengan kualifikasi pendidikan S2 dan S1.

\section{HASIL DAN PEMBAHASAN}

\subsection{Analisis Statistik}

\subsubsection{Uji Validitas dan Reliabilitas}

Kriteria pengujian validitas jika $\rho>r$ tabel maka indikator dinyatakan valid. Dengan menggunakan tabel distribusi (tabel r) untuk $\alpha$ $=0,05$ dan jumlah responden sebanyak 30, sehingga didapat $\mathrm{r}$ tabel $=0,361$. Setelah dilakukan perhitungan dengan teknik Pearson Product Moment dengan persamaan (3) maka untuk kinerja biaya seluruh variabel dinyatakan valid dan untuk kinerja waktu ada tiga variabel yang tidak valid yaitu tenaga inti proyek yang kurang kompeten $\left(\mathrm{X}_{13}\right)$, banyaknya kerja lembur $\left(\mathrm{X}_{15}\right)$ dan pemborosan pemakaian material di lapangan $\left(\mathrm{X}_{21}\right)$. Untuk uji reliabilitas Uji dilakukan dengan melihat nilai alfa Cronbach dengan menggunakan persamaan (4).

Untuk kinerja biaya, nilai alfa Cronbach adalah 0,918 dan untuk kinerja waktu 0,911. Menurut Sekaran (2006) [18] nilai alfa Cronbach yang lebih besar dari 0,6 dikatakan reliabel, maka kedua nilai kinerja tersebut reliabel.

\subsubsection{Analisis Korelasi}

Analisis korelasi merupakan alat analisis yang dipergunakan untuk mengukur korelasi hubungan antara variabel terikat (Y) dengan variabel bebas $(\mathrm{X})$ yang menghasilkan nilai positif atau negatif dengan batasan nilai koefisien korelasi adalah 1 untuk hubungan positif yang berarti hubungan bersifat satu arah dan -1 untuk hubungan negatif yang berarti hubungan bersifat berlawanan.

Analisis korelasi dihitung dengan menggunakan korelasi produk momen Pearson (Bivariate Pearson) pada persamaan (5). 
Analisis korelasi dihitung dengan bantuan Statistical Program for Social Science (SPSS), menggunakan metode Pearson. Variabel bebas $\mathrm{X}$ yang mempunyai korelasi lemah terhadap variabel terikat $Y$ tidak akan diikutkan pada analisis selanjutnya. Besaran koefisien korelasi variabel $\mathrm{X}$ harus lebih besar dari nilai $\mathrm{r}$ tabel dengan signifikansi $5 \%$ pada $n=30$ yaitu 0,361 . Hasil analisis untuk kinerja biaya dan kinerja waktu dapat dilihat pada Tabel 1 dan Tabel 2.

Tabel 1. Signifikan korelasi hubungan hasil analisis Pearson terhadap kinerja biaya $\mathrm{Y}$

\begin{tabular}{ccc}
\hline No. & Kode & $\begin{array}{l}\text { Koef. } \\
\text { Korel. }\end{array}$ \\
\hline 1 & X1 & $-0,395$ \\
2 & X4 & $-0,480$ \\
3 & X7 & $-0,445$ \\
4 & X8 & $-0,427$ \\
5 & X11 & $-0,364$ \\
6 & X12 & $-0,405$ \\
7 & X15 & $-0,435$ \\
8 & X17 & $-0,387$ \\
9 & X22 & $-0,593$ \\
10 & X23 & $-0,509$ \\
11 & X24 & $-0,585$ \\
12 & X25 & $-0,613$ \\
13 & X26 & $-0,508$ \\
14 & X27 & $-0,395$ \\
15 & X28 & $-0,396$ \\
16 & X29 & $-0,395$ \\
\hline
\end{tabular}

Tabel 2. Signifikan korelasi hubungan hasil analisis Pearson terhadap kinerja waktu Y

\begin{tabular}{ccc}
\hline No. & Kode & $\begin{array}{c}\text { Koef. } \\
\text { Korel. }\end{array}$ \\
\hline 1 & X4 & $-0,551$ \\
2 & X8 & $-0,539$ \\
3 & X11 & $-0,392$ \\
4 & X16 & $-0,385$ \\
5 & X25 & $-0,579$ \\
6 & X26 & $-0,381$ \\
7 & X30 & $-0,389$ \\
\hline
\end{tabular}

\subsubsection{Analisis Regresi}

Dengan menggunakan persamaan (6), analisis regresi kinerja biaya menghasilkan persamaan :

$Y=8,607-0,452 X_{22}-0,569 X_{23}-0,367 X_{25}$ dengan :

$\mathrm{Y}=$ Kinerja Biaya Proyek

$\mathrm{X} 22=$ Metode pelaksanaan yang salah

$\mathrm{X} 23=$ Terjadinya redesain

X25 = Cuaca buruk saat aktivitas konstruksi

Dan untuk hasil analisis regresi kinerja waktu menghasilkan persamaan :

$\mathrm{Y}=\mathbf{1 2 , 2 6 2}-1,099 \mathrm{X}_{8}-0,97 \mathrm{X}_{25}$

dengan :

$\mathrm{Y}=$ Kinerja Waktu Proyek

$\mathrm{X} 8 \quad=$ Kerusakan peralatan

X25 = Cuaca buruk saat aktivitas konstruksi

\subsubsection{Pengujian Model Regresi}

Uji model dilakukan untuk meyakinkan persamaan yang terpilih. Untuk mengukur kestabilan model tersebut dilakukan metode uji analisis parametrik sebagai berikut.

- Uji Multikolinearitas

Persyaratan untuk dapat dikatakan terbebas dari multikolinearitas adalah nilai toleransi lebih besar dari 0,10 dan nilai VIF tidak boleh lebih dari 10. Dengan menggunakan persamaan (7), untuk kinerja biaya, nilai toleransi $\mathrm{X}_{22}, \mathrm{X}_{23}$ dan $\mathrm{X}_{25}$ berturut-turut adalah 0,$904 ; 0,927 ; 0,843$, untuk kinerja waktu nilai toleransi $\mathrm{X}_{8}$, dan $\mathrm{X}_{25}$ berturutturut adalah 0,$957 ; 0,957$. Ini berarti bahwa nilai toleransi lebih besar dari 0,10. Dan untuk nilai VIF dengan menggunakan persamaan (8), untuk kinerja biaya berturutturut adalah 1,$106 ; 1,078 ; 1,187$ dan untuk kinerja waktu berturut-turut adalah 1,045 ; 1,045. Ini berarti nilai VIF lebih kecil dari 10. Model yang dihasilkan memenuhi uji multikolinearitas.

- Hasil uji koefisien determinasi

Dengan menggunakan persamaan (9), nilai koefisien determinasi dari model menunjukkan nilai adjusted $R^{2} 67,9 \%$ untuk kinerja biaya dan $R^{2} 72 \%$ untuk kinerja waktu.

- Hasil uji $\mathrm{F}$

Uji $\mathrm{F}$ dilakukan dengan membandingkan $\mathrm{F}$ hitung yang dihitung menggunakan persamaan (10) dengan $\mathrm{F}$ tabel ( $\mathrm{F}$ hitung $>\mathrm{F}$ tabel). Untuk kinerja biaya 21,488 > 3,35 dan untuk kinerja waktu $14,521>4,20$. Kedua nilai tersebut berarti bahwa koefisien variabel bebas $\mathrm{X}$ tidak sama dengan nol atau seluruh variabel bebas $\mathrm{X}$ dari model regresi mempengaruhi variabel Y. 
- Uji t

Uji t dilakukan untuk melihat adanya hubungan linear antara variabel $\mathrm{X}$ dengan variabel Y. untuk memenuhi uji ini maka setiap variabel harus memenuhi $t$ hitung $>\mathrm{t}$ tabel dan nilai signifikansi $<0,05$. $t$ hitung didapatkan dengan menggunakan persamaan (11). Uji t untuk persamaan (13) nilai t hitung setiap variabel berturut-turut adalah 4,317; 3,729; 3,162 > t tabel 2,055. Untuk persamaan (14) nilai t hitung setiap variabel berturut-turut adalah 3,206; 3,575 >t tabel 2,052. Dari hasil pengujian tersebut, tidak terdapat hubungan linear antara faktor dominan terhadap kinerja biaya dan waktu proyek.

Setelah model diuji dan memenuhi berbagai persyaratan di atas, maka nilai kinerja hasil perhitungan dengan menggunakan persamaan hasil analisis dapat dilihat pada Tabel $\mathbf{3}$ dan Tabel 4.

Tabel 3. Kinerja biaya dengan pemodelan regresi

\begin{tabular}{|r|r|r|r|r|r|r|}
\hline Peramalan & Koef & Nilai kasus & \multicolumn{4}{|c|}{ Distribusi normal skor 1-5 } \\
\hline Kinerja & Regresi & & min & maks & rerata & std \\
\hline 2,440 & & & & & & \\
\hline & 8,607 & & & & & \\
\hline$-1,944$ & $-0,452$ & 4,30 & 1 & 5 & 4,30 & 0,99 \\
\hline$-2,634$ & $-0,569$ & 4,63 & 2 & 5 & 4,63 & 0,67 \\
\hline$-1,589$ & $-0,367$ & 4,33 & 2 & 5 & 4,33 & 0,92 \\
\hline
\end{tabular}

Tabel 4. Kinerja waktu dengan pemodelan regresi

\begin{tabular}{|r|r|r|r|r|r|r|}
\hline Peramalan & Koef. & Nilai Kasus & \multicolumn{5}{|c|}{ Distribusi normal skor 1-5 } \\
\hline Kinerja & Regresi & & min & maks & rerata & std \\
\hline 2,634 & & & & & & \\
\hline 12,262 & 12,262 & & & & & \\
\hline$-5,198$ & $-1,099$ & 4,73 & 4 & 5 & 4,73 & 0,45 \\
\hline$-4,430$ & $-0,970$ & 4,57 & 3 & 5 & 4,57 & 0,57 \\
\hline
\end{tabular}

\subsection{Simulasi Monte Carlo}

Model hasil analisis regresi disimulasikan dengan simulasi Monte Carlo dengan bantuan program Crystal Ball untuk mengetahui probabilitas terjadinya variabel penentu. Proses simulasi pada penelitian ini dilakukan terhadap variabel terikat $\mathrm{Y}$ dengan menggunakan model hasil analisis regresi pada persamaan (11) dan persamaan (12). Simulasi dilakukan sebanyak 10.000 iterasi. Kinerja biaya disimulasikan dengan kemungkinan skenario yang terjadi sebanyak 27 skenario dan untuk kinerja waktu sebanyak 9 skenario.
Untuk kinerja biaya diperoleh indeks dasar dengan tingkat kepastian $90 \%$ dari nilai $Y$ adalah 3,769 dan untuk kinerja waktu diperoleh indeks dasar dengan tingkat kepastian 90\% adalah 3,304. Hasil simulasi yang dituangkan dalam grafik dapat dilihat pada Gambar 2 dan Gambar 3.

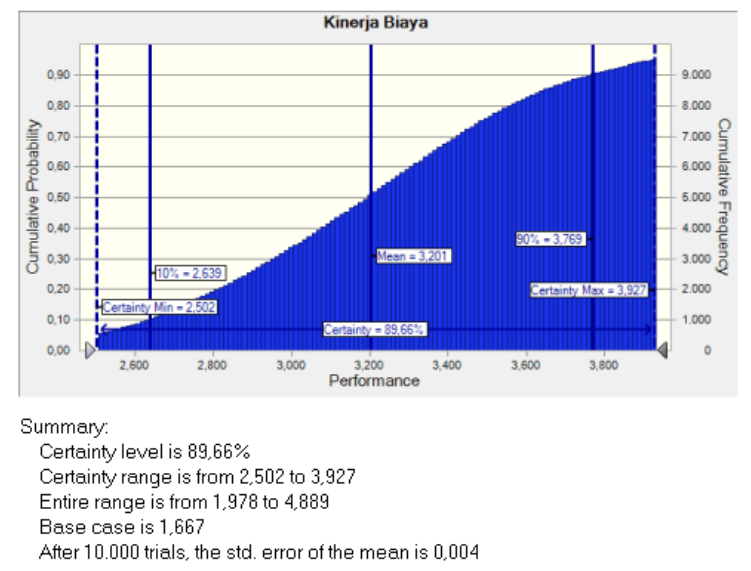

Gambar 2. Grafik simulasi peramalan kinerja biaya (Y)

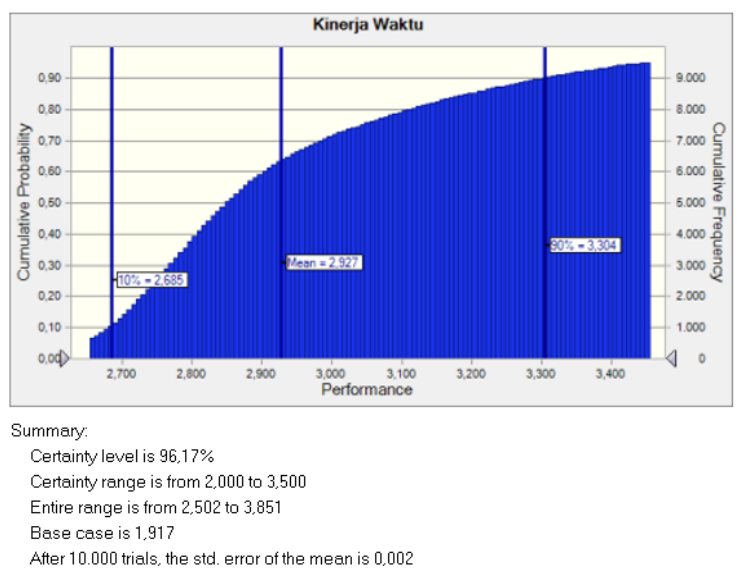

Gambar 3. Grafik simulasi peramalan kinerja waktu (Y)

Hasil ini menunjukkan bahwa nilai tersebut menjadi batas nilai untuk menunjukkan bahwa nilai kinerja (Y) baik jika lebih besar dari probabilitas $90 \%$ atau tidak dengan berada di bawah probabilitas tersebut. Ilustrasi ditampilkan pada Gambar 4 dan Gambar 5. 


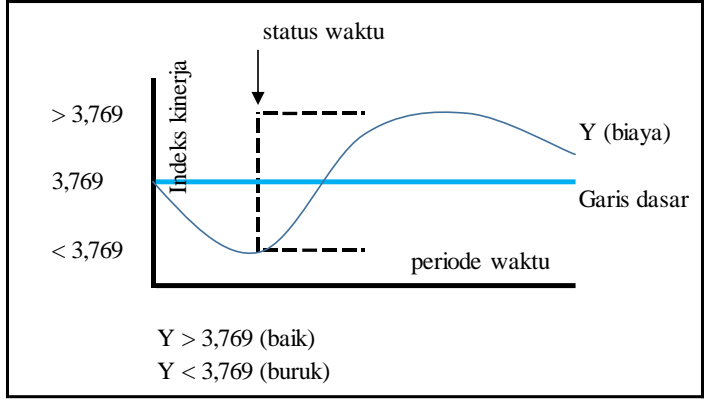

Gambar 4. Ilustrasi grafik hasil kinerja (Y) biaya model regresi

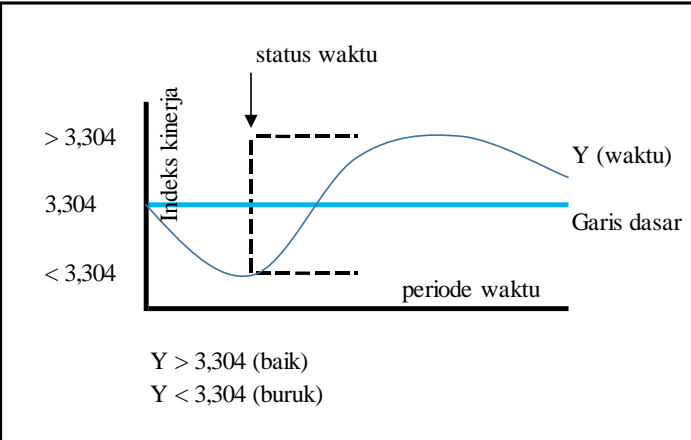

Gambar 5. Ilustrasi grafik hasil kinerja (Y) waktu model regresi

\subsection{Earn Value Analysis}

Kemajuan pekerjaan dapat dilihat dari bobot serta biaya berdasarkan rencana dan pengeluaran. Data Budget Cost of Work Schedule (BCWS), Budget Cost of Work Performance (BCWP) dan Actual Cost of Work Performance (ACWP) dapat dilihat dari Tabel 5 dan Gambar 6.

Tabel 5. Earn Value Analysis Proyek Konstruksi Asrama Haji Gorontalo dalam jutaan rupiah

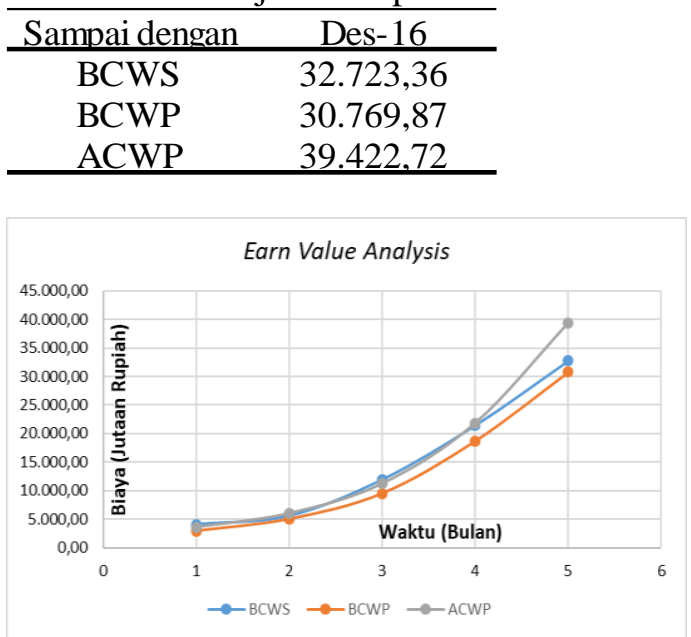

Gambar 6. Grafik Earn Value Analysis Proyek Konstruksi Asrama Haji Gorontalo
Untuk mengetahui faktor efisiensi biaya dan waktu dapat diketahui dengan menghitung CPI (Cost Performance Index) dan SPI (Schedule Performance Index).

\subsubsection{Cost Performance Index (CPI)}

CPI dihitung menggunakan persamaan (1). Perhitungan CPI bulan ke-5 (Desember 2016)

$$
\begin{aligned}
& C P I=\frac{30.769,87}{39.422,72} \\
& C P I=0,78
\end{aligned}
$$

Nilai CPI ini menunjukkan bobot nilai yang diperoleh terhadap biaya yang dikeluarkan. Nilai CPI kurang dari 1 menunjukkan kinerja biaya yang kurang baik, karena biaya yang dikeluarkan (ACWP) lebih besar dibanding dengan nilai yang didapat (BCWP), dalam arti pengeluaran lebih besar dari anggaran atau Over Budget.

\subsubsection{Schedule Performance Index (SPI)}

SPI dihitung menggunakan persamaan (1). Perhitungan SPI bulan ke-5 (Desember 2016)

$$
\begin{aligned}
& S P I=\frac{32.723,36}{39.422,72} \\
& S P I=0,83
\end{aligned}
$$

Nilai SPI ini menunjukkan seberapa besar pekerjaan yang mampu diselesaikan terhadap satuan pekerjaan yang direncanakan. Nilai SPI kurang dari 1 menunjukkan kinerja waktu yang kurang baik karena berjalan lebih lambat dari target yang direncanakan atau Behind Schedule.

Dari nilai kinerja hasil pemodelan statistik dan analisis nilai hasil (Earn Value Analysis) maka perbandingan di antara kedua hasil tersebut dapat dilihat pada Tabel 6.

Tabel 6. Perbandingan nilai kinerja hasil model statistik dengan earn value analysis

\begin{tabular}{lcc}
\hline Kinerja & Model statistik & EVA \\
\hline Biaya & $2,440<3,769$ & $0,78<1$ \\
Waktu & $2,634<3,304$ & $0,83<1$ \\
\hline
\end{tabular}

Dari Tabel 6 dapat dilihat bahwa kedua hasil berada di bawah indeks dasar yang berarti hasil kedua analisis tersebut mempunyai hasil yang selaras.

\subsection{Analisis Dampak, Penyebab dan Respons Risiko}

Risiko-risiko yang mempunyai pengaruh signifikan terhadap kinerja biaya maupun waktu yang teridentifikasi yaitu : 
1. Variabel X8 - Kerusakan peralatan

Dampak yang ditimbulkan terkait rusaknya alat adalah proses pengadaan alat baru yang membutuhkan biaya dalam penyewaan dan transportasi. Penyebab adalah kondisi alat yang tidak optimal. Respons yang dapat diambil adalah memberitahukan kepada pihak penyewaan alat dan melakukan penggantian secepatnya dengan mempertimbangkan biaya dan waktu.

2. Variabel X22 - Metode pelaksanaan yang salah

Dampak yang ditimbulkan yaitu menambah pengeluaran untuk memperbaiki pekerjaan yang salah. Penyebabnya adalah pengalaman pelaksanaan konstruksi pekerja yang rendah. Respons yang dapat dilakukan adalah dengan melakukan pelatihan dalam melakukan pekerjaan (on the job training) serta pengawasan yang lebih ketat.

3. Variabel X23 - Terjadinya redesain (rework)

Dampak yang dapat terjadi adalah bertambahnya pengeluaran untuk mengganti biaya pekerjaan baik dari alat, bahan maupun pekerja. Penyebab terjadinya redesain dapat terjadi akibat berbagai kesalahan dalam pelaksanaan atau pun kesalahan dari desain. Respons yang dapat diambil adalah melakukan pengawasan yang ketat, meninjau kembali desain yang berpotensi menyebabkan redesain.

4. Variabel X25 - Cuaca buruk saat aktivitas konstruksi

Dampak yang ditimbulkan adalah tertundanya pekerjaan pada lintasan kritis. Penyebabnya adalah cuaca yang ekstrem akibat pemanasan global. Respons yang dapat diambil adalah dengan membuat perencanaan terhadap lintasan kritis beserta total waktu mengambang (total float/slack) dan melakukan kerja lembur.

\section{KESIMPULAN DAN SARAN}

\subsection{Kesimpulan}

1. Variabel-variabel risiko yang dominan terhadap kinerja biaya yaitu Metode pelaksanaan yang salah, terjadinya redesain (rework) dan cuaca buruk saat aktivitas konstruksi. Sedangkan variabel-variabel risiko yang dominan terhadap kinerja waktu yaitu kerusakan peralatan dan cuaca buruk saat aktivitas konstruksi.
2. Model statistik yang dihasilkan untuk kinerja biaya adalah : $\mathrm{Y}=8,607-0,452 \mathrm{X}_{22}-0,569 \mathrm{X}_{23}-0,367 \mathrm{X}_{25}$ dan untuk kinerja waktu adalah : $\mathrm{Y}=12,262-1,099 \mathrm{X}_{8}-0,97 \mathrm{X}_{25}$

3. Hasil CPI dan SPI memperlihatkan bahwa pekerjaan konstruksi melebihi anggaran (over budget) dan terlambat dari jadwal (behind schedule). Model yang dibuat mempunyai hasil yang selaras dengan analisis nilai hasil (Earn Value Analysis) dan dapat digunakan sebagai pembanding di lapangan.

4. Dampak dan penyebab risiko :

- Dampak : Progres pekerjaan konstruksi tidak tercapai dan penalti dari pihak pemilik.

- Penyebab : Tidak dapat memprediksi perubahan cuaca, penggantian alat rusak yang terlambat serta pekerja yang kurang berpengalaman .

\subsection{Saran}

1. Bagi kontraktor pelaksana.

Untuk meningkatkan kinerja, faktor risiko tersebut harus direspons dan ditindak dengan baik sehingga meminimalkan segala kemungkinan yang menyebabkan kerugian biaya maupun keterlambatan, terutama dari faktor cuaca yang penyebabnya sulit untuk diantisipasi, perencanaan yang tepat dalam melakukan pekerjaan konstruksi yang bersifat terbuka dengan melihat data curah hujan tahunan sekiranya dapat mengurangi dampak risiko.

2. Bagi pemilik (owner) / pemerintah

Waktu pekerjaan dari tahapan pelelangan sampai selesai pelaksanaan pekerjaan yang dilaksanakan dalam satu periode tahun anggaran tidaklah cukup untuk melaksanakan pekerjaan berskala besar. Hal ini bisa berdampak pada kinerja yang buruk sehingga mendapatkan kualitas yang kurang memuaskan pemilik proyek.

3. Bagi Penelitian selanjutnya

Untuk penelitian selanjutnya, penilaian dari pemodelan yang telah dibuat dapat dibandingkan dengan penilaian kinerja dari analisis nilai hasil (Earn Value Analysis) sehingga mendapatkan perbandingan keakuratan juga membandingkan dengan hasil akhir yang dicapai oleh pelaksanaan proyek. Demikian juga untuk antisipasi terhadap cuaca yang buruk, penelitian selanjutnya dapat meneliti strategi yang tepat dalam 
mengantisipasi ataupun menindak risiko ini. Standar untuk skala penilaian dicantumkan pada kuesioner dengan lebih jelas sehingga responden memiliki batasan sesuai keinginan peneliti dalam menentukan jawaban pilihan.

\section{DAFTAR PUSTAKA}

[1]Kerzner, Harold. (2003). Project Management: A Systems Approach to Planning, Scheduling, and Controlling. Wiley.

[2]Yahya, I.N. (2011). Pengelolaan Risiko Proyek Pembangunan PLTU 10.000 MW Dalam Rangka Peningkatan Kinerja Biaya. Tesis Universitas Indonesia. Jakarta.

[3]Utama, H. \& Setiadi, B. (2013). Identifikasi Dan Analisa Faktor Risiko Yang Berpengaruh Terhadap Biaya Pelaksanaan Konstruksi Baja Bangunan Gedung Bertingkat. Teknik Sipil Fakultas Teknik Universitas Indonesia. Jakarta.

[4]PMI. (2013), A Guide to The Project Management Body of Knowledge (PMBOK Guide) Fifth Edition. Project Management Institute, Inc.

[5]Sitomorang, Y. G. (2009) Analisis Produktivitas Pekerja Proyek Konstruksi Pada Perusahaan Kontraktor Di Jakarta, Laporan Tugas Akhir S1, TS FT. Universitas Atma Jaya Yogyakarta.

[6]Alinaitwe, Mwanaki, Mwakali, and Hansson, (2008), Factors Affecting the Performance of Pavement Road Construction Projects in Uganda, School of Built Environment / College of Engineering, Design, Art and Technology, Makerere University, Uganda

[7]Widiyanto, Joko. (2010). SPSS for Windows Untuk Analisis Data Statistik dan Penelitian. Surakarta: BP-FKIP UMS.
[8]Draper,N.R,Smith,H.(2014).Applied Regression Analysis, Third Edition. Wiley

[9]Santoso, S. (2012). Analisis SPSS pada Statistik Parametrik. PT.Elex Media Komputindo. Jakarta

[10]Ghozali, I. (2006). Aplikasi Analisis Multivariate dengan SPSS, Cetakan Keempat, Badan Penerbit Universitas Diponegoro, Semarang.

[11]Sugiyono. Prof. Dr. (2013), Metode Penelitian Kuantitatif, Kualitatif Dan $R \& D$, Bandung: Alfabeta, CV.

[12]Rawlings, J.O., Pantula, S.G., dan Dickey, D.A. (1998) Applied Regression Analysis: A Research Tool. USA : Springer.

[13]Rubeinstein, R.Y. (2007) Simulation and the Monte Carlo Method, 2nd Edition. Wiley.

[14]Asmarantaka, N.S. (2014). Analisis Risiko Yang Berpengaruh Terhadap Kinerja Proyek Pada Pembangunan Hotel Batiqa Palembang. Jurnal Teknik Sipil dan Lingkungan Vol.2. No.3.

[15]Nurlela \& Suprapto, H. (2014). Identifikasi Dan Analisis Manajemen Risiko Pada Proyek Pembangunan Infrastruktur Bangunan Gedung Bertingkat. Jurnal Desain Konstruksi. Volume 13. No. 2.

[16]Andi., Winata, S. \& Hendarlim, Y. (2005). Faktor-Faktor Penyebab Rework Pada Pekerjaan Konstruksi. Civil Engineering Dimension. Vol.7. No.1.

[17]Janaka, Y.R (2006). Project Planning and Scheduling its Impact to Project Outcome. AACE Journal.

[18]Sekaran, U. (2006), Metodologi Penelitian untuk Bisnis, Edisi 4, Buku 1, Jakarta: Salemba Empat. 